\title{
Tetrodotoxin Detection by a Surface Plasmon Resonance Sensor in Pufferfish Matrices and Urine
}

\author{
Allen D. Taylor, ${ }^{1}$ Hana Vaisocherová, ${ }^{1}$ Jonathan Deeds, ${ }^{2}$ Stacey DeGrasse, ${ }^{2}$ and Shaoyi Jiang ${ }^{1}$ \\ ${ }^{1}$ Department of Chemical Engineering, University of Washington, Box 351750, Seattle, WA 98195, USA \\ ${ }^{2}$ Center for Food Safety and Applied Nutrition, U.S. Food and Drug Administration, College Park, MD 20740, USA
}

Correspondence should be addressed to Stacey DeGrasse, stacy.degrasse@fda.hhs.gov and Shaoyi Jiang, sjiang@uw.edu

Received 24 April 2011; Accepted 26 May 2011

Academic Editor: Andrea Cusano

Copyright ( $) 2011$ Allen D. Taylor et al. This is an open access article distributed under the Creative Commons Attribution License, which permits unrestricted use, distribution, and reproduction in any medium, provided the original work is properly cited.

\begin{abstract}
Tetrodotoxin (TTX) poisoning is most commonly associated with consumption of pufferfish. TTX is a low molecular weight $(\sim 319 \mathrm{Da})$ neurotoxin that selectively blocks voltage-sensitive $\mathrm{Na}^{+}$-gated ion channels. The standard method accepted worldwide for monitoring TTX toxicity in food matrices is the mouse bioassay. Ethical concerns from live animal testing, low sample throughput, and analytical inaccuracies have led to the need for an alternative method. We have previously established that surface plasmon resonance (SPR) sensors can quantify TTX in aqueous buffer samples by an antibody-based inhibition assay. In this paper, we report the extension of the assay for the detection of TTX in both clinical- and food-relevant matrices. The assay was optimized for application to three relevant complex matrices: pufferfish liver extract, pufferfish muscle extract, and human urine. Matrix effects are discussed and calibration curves are presented. Naturally contaminated pufferfish liver and muscle extracts were analyzed by the SPR method, and the data is compared to liquid-chromatography electrospray-ionization multiple reactions monitoring mass spectrometry (LC/ESI/MRM/MS) data. Ten samples, including three from a poisoning incident, two control monkfish samples, and five toxic pufferfish samples, were analyzed using this method, and the data is compared to $\mathrm{LC} / \mathrm{ESI} / \mathrm{MRM} / \mathrm{MS}$ analysis of the samples.
\end{abstract}

\section{Introduction}

Tetrodotoxin (TTX) poisoning is most commonly associated with consumption of pufferfish. TTX is a low molecular weight $(\sim 319 \mathrm{Da})$ neurotoxin that has been discovered in several animal species including pufferfish, newts, toads, octopus, arrow worms, and xanthid crabs [1]. Several analogues of the base molecule have also been identified, all of which exhibit the toxic effect of selectively blocking voltagesensitive $\mathrm{Na}^{+}$-gated ion channels [2]. Symptoms of TTX poisoning are manifested in humans as perioral numbness and paresthesia, distal limb numbness and paresthesia, ataxia, dizziness, and muscle weakness. In severe cases respiratory muscle paralysis, coma, hypotension and cardiac dysrhythmias occur with fatal consequences [3]. The lethal dose of TTX for mammals that causes death in $50 \%$ of a group of test animals $\left(\mathrm{LD}_{50}\right)$ is $2-10 \mu \mathrm{g} / \mathrm{kg}$ intravenously and $10-14 \mu \mathrm{g} / \mathrm{kg}$ subcutaneously [4].

The most common source of TTX poisoning is the Japanese pufferfish (Takifugu spp.) which preferentially accu- mulates TTX in high concentrations in the skin, liver, ovary, and intestines [5]. However, the muscle can also contain lethal concentrations [6]. The muscle is often consumed as a delicacy in Japan and requires special processing from trained and licensed individuals [3]. In recent years, several cases of TTX poisoning in the United States and Mexico have occurred from the consumption of pufferfish from the Atlantic Ocean, Gulf of Mexico, and Gulf of California [7].

For diagnosis of poisoning incidents, the suspected source (i.e., meal remnant) is often not available for analysis. Thus, it is necessary to also be able to analyze clinical samples collected from the patient. Two independent studies have been published, reporting concentrations of TTX in the urine and blood of patients from poisoning incidents using chromatography-based methods [8,9]. A study by Kawatsu et al. quantified TTX in urine by immunoaffinity chromatography and high performance liquid chromatography (HPLC) in twelve samples from six poisoned patients collected from 1989 to 1996. They reported concentrations 
of TTX in urine ranged from 6 to $100 \mathrm{ng} / \mathrm{mL}$ and required a sample volume of $100 \mathrm{~mL}$ for analysis [8]. In another study, Tsia et al. quantified TTX in urine and blood by liquid chromatography-mass spectrometry (LC-MS) from six poisoned fishermen. The concentration of TTX in blood ranged from 1.4 to $13 \mathrm{ng} / \mathrm{mL}$ and from 15 to $110 \mathrm{ng} / \mathrm{mL}$ in urine. The samples were collected approximately 10 hours after ingestion of the toxic fish and one patient died shortly after eating the toxic fish. The patient that died had TTX levels of $104 \mathrm{ng} / \mathrm{mL}$ in urine and $13 \mathrm{ng} / \mathrm{mL}$ in blood. The study showed that the concentration of TTX in urine is substantially higher than in blood 10 hours after ingestion indicating that TTX is easily metabolized and excreted in urine [9]. Therefore, urine is the preferable clinical matrix for testing for TTX poisoning.

The standard method accepted worldwide for determining TTX toxicity in food matrices is the mouse bioassay [10]. Ethical concerns from live animal testing [11] and the cost and labor, low sample throughput, and analytical inaccuracies associated with variances from live animals and sample matrices [12] have led to the need for an alternative method to the mouse bioassay. Biological methods for determining TTX toxicity such as receptor binding assays [13], cytotoxicity tests [14], and electrophysiological assays [15] have been demonstrated. Also, analytical methods such as HPLC and mass spectrometry can identify and quantify TTX and its naturally occurring congeners $[16,17]$. Immunological methods, such as enzyme-linked immunosorbant assay (ELISA), have become popular in recent years because they are inexpensive, sensitive, and selective. An inhibition-type ELISA has been previously reported for quantification of TTX using a commercially available antibody $[5,18,19]$. Also, we have previously reported an inhibition immunoassay for quantification of TTX using a surface plasmon resonance (SPR) sensor [20]. SPR sensors can perform faster detections with high sensitivity and specificity. The advantages of SPR sensors as compared to other biosensor technologies is their ability to provide label-free and realtime detections for direct and continuous monitoring of biomolecular interactions $[21,22]$. In our previous study, a surface was developed that specifically bound TTX antibody and resisted nonspecific adsorption from nonspecific antibodies and bovine serum albumen (BSA) [20]. The optimized inhibition assay demonstrated a detection limit of $\sim 0.3 \mathrm{ng} / \mathrm{mL}$ in buffer, and the biochip was reproducibly regenerated for at least ten sample detection cycles.

In this work, we report the extension of the inhibitionbased immunoassay by SPR sensor to the detection of TTX in both clinical and food relevant matrices. The assay was optimized for application to three complex matrices: pufferfish liver, muscle extracts, and human urine. The effect of each unique matrix on the assay and the surface is discussed. Calibration curves based on samples spiked with TTX standard are presented for each matrix. Samples of naturally contaminated pufferfish liver and muscle extracts were analyzed by the SPR method and compared to analysis from liquid-chromatography electrospray-ionization multiple reactions monitoring mass spectrometry (LC/ESI/MRM/MS). Ten samples, including three from a poisoning incident, two control monkfish samples, and five toxic pufferfish samples were also analyzed and compared to $\mathrm{LC} / \mathrm{ESI} / \mathrm{MRM} / \mathrm{MS}$ analysis of the samples.

\section{Materials and Methods}

2.1. Materials. TTX was produced by Sankyo Co, Ltd. (Tokyo, Japan). Monoclonal rabbit antibody for tetrodotoxin (anti-TTX) was purchased from Hawaii Biotech, Inc. (Aiea, HI, USA) [5]. Lyophilized human urine, bovine serum albumen (BSA), phosphate buffered saline (PBS) (0.01 M phosphate, $0.138 \mathrm{M}$ sodium chloride, $0.0027 \mathrm{M}$ potassium chloride, $\mathrm{pH}$ 7.3), sodium acetate, hydrochloric acid, acetic acid, sodium hydroxide, and sodium chloride were from SigmaAldrich (St. Louis, MO, USA). Hydroxyl-terminated oligoethylene glycol( $\mathrm{OEG})$-alkanethiol ( $\mathrm{HS}-\left(\mathrm{CH}_{2}\right)_{11}-\left(\mathrm{O}\left(\mathrm{CH}_{2}\right)_{2}\right)_{4}$ $\mathrm{OH})$ and amine-terminated OEG-alkanethiol (HS- $\left(\mathrm{CH}_{2}\right)_{11}$ $\left(\mathrm{O}\left(\mathrm{CH}_{2}\right)_{2}\right)_{6} \mathrm{NH}_{2}$ ) were purchased from ProChimia (Gdansk, Poland). Formaldehyde (37\%) was purchased from J.T. Baker (Phillipsburg, NJ, U.S.A.). Naturally contaminated pufferfish muscle and liver extracts as well as samples collected during a toxic pufferfish outbreak case were provided by the FDA Center for Food Safety and Applied Nutrition (CFSAN).

\subsection{Antibody-Based Inhibition Assay for Quantification of} TTX by SPR Sensor. The methods and instrumentation used in this study were detailed in a previous publication that presents the development of an antibody-based inhibition assay for detection of TTX by SPR sensor [20]. The SPR sensor used in this work was a custom-built instrument based on the Kretschmann geometry of the attenuated total reflection (ATR) method and wavelength interrogation. For this SPR sensor, a $1 \mathrm{~nm}$ SPR wavelength shift at $750 \mathrm{~nm}$ to $751 \mathrm{~nm}$ represents a surface coverage of $\sim 161 \mathrm{pg} / \mathrm{mm}^{2}$ for proteins. The SPR biochips that exhibit specific binding of anti-TTX and resist protein fouling were coated with a self-assembled monolayer (SAM) consisting of amine terminated OEG alkanethiol and a hydroxyl terminated OEG alkanethiol. TTX molecules were then covalently linked to the exposed amine terminal group in the mixed SAM surface in an orientation that favors anti-TTX binding. The ratio of amine to hydroxyl terminated OEG alkanethiols and TTX chemistry were previously optimized to maximize specific anti-TTX binding, while minimizing nonspecific protein binding. An inhibition assay was used with the SPR sensor and functional SPR biochip to quantitatively detect TTX. The inhibition assay was performed by mixing a fixed concentration of anti-TTX with samples containing unknown TTX concentrations or known standards for determination of calibration curves. During the incubation period, TTX in the sample will bind to the anti-TTX paratope, reducing the number of antibodies with antigen-free binding sites. The samples were then flowed over the SPR biochip, and the SPR sensor detects the amount of antigen-free antiTTX that binds to the surface. The SPR sensor response was directly related to the amount of antigen-free anti-TTX in the sample and therefore inversely related to the amount of TTX. Thus the maximum sensor response corresponds 
to zero TTX in the sample, and a zero sensor response corresponds to total inhibition of anti-TTX binding, therefore a concentration of TTX outside of the quantifiable range of the method. Calibration curves for each detection matrix were calculated by normalizing the response from standards containing $10 \mathrm{pg} / \mathrm{mL}$ to $10 \mu \mathrm{g} / \mathrm{mL}$ TTX incubated with a fixed concentration of anti-TTX to the maximum response of the anti-TTX at the same concentration. Matrix effects on the anti-TTX binding were taken into account and appropriate standards were developed for each matrix and are discussed in this paper. The unit for normalized data was percent inhibition, which refers to the percentage of total response divided by the maximum response from only the antibody. Detection limit and detection range are commonly expressed as percent inhibitory concentration, which refers to the concentration of inhibitory molecule (TTX) needed to lower the maximum response to a certain percentage. For the work, the detection limit was $20 \%$ inhibitory concentration $\left(\mathrm{IC}_{20}\right)$ and the quantifiable range was $\mathrm{IC}_{20}$ to $80 \%$ inhibitory concentration $\left(\mathrm{IC}_{80}\right)$.

2.3. Pufferfish Tissue Extraction Method. Either whole organs (if $<5 \mathrm{~g}$ ) or $5 \mathrm{~g}$ subsamples of homogenized tissues were extracted twice with $10 \mathrm{~mL}$ of $1 \%$ acetic acid in methanol. Samples were homogenized using a motorized tissue homogenizer (Polytron PT 10-35 with a $12 \mathrm{~mm}$ generator, Kinematica AG, Switzerland), centrifuged, and combined supernatants were concentrated to $<1 \mathrm{~mL}$ under vacuum. Samples were redissolved in $5 \mathrm{~mL}$ of $1 \%(\mathrm{v} / \mathrm{v})$ acetic acid in High Performance Liquid Chromatography (HPLC) grade water, then defatted with chloroform. To do this, $5 \mathrm{~mL}$ of chloroform was added to samples, vortexed to mix, then separated by centrifugation. The top aqueous layer was saved, $5 \mathrm{~mL}$ of additional acidified water was added to the lower chloroform layer, and the process was repeated. The supernatants were combined giving an extract equivalent to $0.5 \mathrm{~g}$ tissue $/ \mathrm{mL}$. According to Chen and Chou [23], this method provided $>90 \%$ extraction efficiency. In previous experiments, we spiked homogenized puffer fish muscle $(n=$ $3)$, liver $(n=2)$, and phosphate buffered saline $(n=2)$ with $10 \mu \mathrm{g} / \mathrm{mL}$ TTX and achieved an average of $86.4 \pm 18.9 \%$ recovery (data not shown).

2.4. Analysis of Samples by LC/ESI/MRM/MS. Initial toxin separations were performed according to Negri et al. [24]. An aliquot of each extract was filtered using a $0.22-\mu \mathrm{m}$ cellulose acetate syringe filter, adjusted to a final concentration of $25 \%$ acetonitrile, and $10 \mu \mathrm{l}$ was injected into an Agilent 1100 HPLC system equipped with a $250 \mathrm{~mm} \times 2 \mathrm{~mm}$ inner diameter column packed with 5- $\mu \mathrm{m}$ TosoHaas TSK-GEL Amide-80 material. Toxins were eluted with $0.3 \mathrm{~mL} \cdot \mathrm{min}^{-1}$ of acetonitrile: HPLC grade water $(70: 30, \mathrm{v} / \mathrm{v})$ with $5 \mathrm{mM}$ ammonium formate and $26.5 \mathrm{mM}$ formic acid. Mass spectrometry was performed with an API5000 (Applied Biosystems/MDS Sciex, Framingham, MA) equipped with a turbospray ionization source and operated in positive ion mode. The following instrument parameters were used: source temperature, $300^{\circ} \mathrm{C}$; curtain gas (CUR), 45L N2/hr; nebulizer gas (GS1),
$40 \mathrm{~L} \mathrm{~N}^{2} / \mathrm{hr}$; turbo heater gas (GS2), 35L N $2 / \mathrm{hr}$; spray voltage, $3200 \mathrm{~V}$. Multiple reaction monitoring (MRM), in which the parent ion for each toxin is fragmented and monitored for the appearance of specific fragments characteristic of that compound, was used for measurement of the toxins. The MRM data acquisition method was separated into two periods, monitoring three fragmentation channels (MRM's) each. The three reactions monitored for TTX were from the decomposition of the protonated TTX molecule $[\mathrm{M}+\mathrm{H}]^{+}$at $\mathrm{m} / \mathrm{z} 320$ fragmenting to ions at $\mathrm{m} / \mathrm{z} 302,256$, and 162. A similar approach was used successfully to quantify TTX by Shoji et al. [17]. Dwell time for each reaction was $200 \mathrm{msec}$ and entrance potential (EP) was $10 \mathrm{~V}$ for each. Declustering potential (DP), collision energy (CE), and exit potential (CXP) were independently optimized for each reaction using Analyst software (v 1.4.2) (Applied Biosystems/MDS Sciex, Framingham, MA). TTX was quantified by linear regression of the sum of the three fragment ions, using standards of the following concentrations: $1,10,100,1,000$ and $10,000 \mathrm{ng} / \mathrm{mL}$ TTX. Standards were diluted in $1 \%$ aqueous acetic acid with $25 \%$ acetonitrile.

\section{Results and Discussion}

3.1. Assay Development for Complex Media. Both the hydroxyl-terminated OEG-alkanethiol and amine-terminated OEG-alkanethiol components of the mixed SAM contain ethylene glycol units, which have been shown to minimize nonspecific binding of proteins [25]. While significant progress has been made in creating sensor surfaces resistant to protein adsorption, it is still difficult to produce surfaces that completely resist adsorption from real-world complex media [26]. Several nonfouling surface platforms have been investigated such as poly(ethylene glycol-) (PEG-) based $[27,28]$ or zwitterionic materials $[29,30]$. The TTX immobilized sensing surface has previously been shown to be nonfouling to $1 \mathrm{mg} / \mathrm{mL}$ BSA and $10 \mu \mathrm{g} / \mathrm{mL}$ anti-hCG, using standard PBS buffer solution at $\mathrm{pH}$ 7.4. Using the previously established assay conditions the sensing surface was tested for nonspecific binding from complex media including urine, pufferfish liver extract, and pufferfish muscle extract. The samples matrices exhibited minimal nonspecific binding.

For detection in complex matrices, $200 \mu \mathrm{g} / \mathrm{mL}$ BSA was added to the assay running buffer and sample diluent. BSA is routinely added to immunoassay running buffers to reduce nonspecific binding and protect protein conformation to reserve their biological activity. However, when urine samples were diluted using $200 \mu \mathrm{g} / \mathrm{mL}$ BSA in PBS at pH 7.4, the $10 \%$ urine sample produced an unusual response (Figure 1), and the baseline did not restabilize for at least 20 minutes after injection. Injection of only BSA or $10 \%$ urine in PBS at $\mathrm{pH} 7.4$ produced a step response corresponding to a bulk refractive index change. Also, $10 \%$ pufferfish liver and muscle extract, diluted using $200 \mu \mathrm{g} / \mathrm{mL}$ BSA in PBS, produced responses similar to the response from samples diluted in only buffer. Testing the $\mathrm{pH}$ of the $10 \%$ pufferfish extract diluted in PBS revealed that the final $\mathrm{pH}$ of the diluted sample was actually $\sim 4-5$. The pufferfish extract was $1 \% \mathrm{v} / \mathrm{v}$ acetic acid, which was used for dissociating TTX from tissue 




FIGURE 1: SPR sensorgram showing sensor response to (1) PBS at pH 7.4 with $200 \mu \mathrm{g} / \mathrm{mL}$ BSA for 10 minutes, followed by (2) $10 \%$ urine in PBS at $\mathrm{pH} 7.4$ with $200 \mu \mathrm{g} / \mathrm{mL}$ BSA for 30 minutes. The spike in the data at 10 minutes is an unexpected response and does not stabilize until 20 minutes after injection. A $1 \mathrm{~nm} \mathrm{SPR}$ wavelength shift at $750 \mathrm{~nm}$ to $751 \mathrm{~nm}$ represents a protein surface coverage of $\sim 161 \mathrm{pg} / \mathrm{mm}^{2}$.

and provides stable $\mathrm{pH}$ for the TTX molecules stored in the extract. Upon further testing, the nontypical response from the urine samples spiked with TTX and diluted with BSA was found to be associated with the $\mathrm{pH}$ of the running buffer. Changing the buffer from PBS at $\mathrm{pH} 7.4$ to sodium acetate (SA) buffer at $\mathrm{pH} 4.5$ eliminated the nontypical response caused by the combination of TTX immobilized surface, BSA, and urine (Figure 2(c)). It is hypothesized that TTX will associate strongly with proteins at neutral $\mathrm{pH}$ because of the strong charge associated with the guanidinium group. It is well known that in order to extract TTX from tissue, it requires solutions at low $\mathrm{pHs}$ [23]. The last modification to running buffer was increasing the buffer capacity, since the $10 \%$ pufferfish extract samples were outside of the buffer capacity of the PBS. The PBS was $10 \mathrm{mM}$ buffer components, so the buffer concentration was increased to $100 \mathrm{mM}$ in order to have enough buffering capacity for $10 \%$ samples of pufferfish extract. The optimized running buffer for complex media was $100 \mathrm{mM}$ SA buffer at $\mathrm{pH} 4.5$ with $50 \mathrm{mM} \mathrm{NaCl}$ and $200 \mu \mathrm{g} / \mathrm{mL}$ BSA (SAB). The optimized assay conditions for complex media resulted in surfaces that remain nonfouling to $10 \%, 1 \%$, and $0.1 \%$ solutions of each matrix (Figure 2). Thus, the assay conditions were suitable for direct detection of antibody binding to the TTX-immobilized sensing surface. The response seen at 10 minutes and 25 minutes was a bulk refractive index shift caused by the difference in refractive index of the running buffer and diluted complex media.

3.2. Detection of TTX in $100 \mathrm{mM}$ Sodium Acetate Buffer at $\mathrm{pH}$ 4.5. Changing the $\mathrm{pH}$ has the most significant effect on the calibration curve, because of the antibody-antigen binding dependence on $\mathrm{pH}$. Typically antibodies have the highest response at $\mathrm{pHs}$ close to physiological $\mathrm{pH}$ of 7.4 in solution and are less active at higher or lower $\mathrm{pH}$, however, immobilization of antibodies on surfaces can affect optimum protein activity. In the case of the anti-TTX, the overall response from $2 \mu \mathrm{g} / \mathrm{mL}$ anti-TTX in PBS at $\mathrm{pH} 7.4$ was $\sim 7.5 \mathrm{~nm}$ and in SA buffer at $\mathrm{pH} 4.5$ was reduced to $\sim$ $1.6 \mathrm{~nm}$ of SPR wavelength shift. The response of anti-TTX at the lower $\mathrm{pH}$ is sufficient for an antibody inhibition assay. However, lower antibody response will affect the calibration curve. Figure 3(a) shows averaged normalized SPR sensorgrams corresponding to the detection of various concentrations of TTX in SAB. Figure 4 shows the calibration curve for normalized wavelength shift versus concentration of TTX in sample with error bars. From the data shown in Figure 4 , the $\mathrm{IC}_{80}, \mathrm{IC}_{50}$, and $\mathrm{IC}_{20}$ for samples incubated with $2 \mu \mathrm{g} / \mathrm{mL}$ anti-TTX are $226 \mathrm{ng} / \mathrm{mL}, 38 \mathrm{ng} / \mathrm{mL}$, and $10 \mathrm{ng} / \mathrm{mL}$, respectively. Thus, the detection limit corresponds to the $\mathrm{IC}_{20}$ of $10 \mathrm{ng} / \mathrm{mL}$. The $\mathrm{IC}_{80}, \mathrm{IC}_{50}$ and $\mathrm{IC}_{20}$ for detection TTX in phosphate buffered saline (PBS) at pH 7.4 with $2 \mu \mathrm{g} / \mathrm{mL}$ antiTTX was 74,13 , and $2 \mathrm{ng} / \mathrm{mL}$ [20]. The $\mathrm{IC}_{80}, \mathrm{IC}_{50}$, and $\mathrm{IC}_{20}$ for detection in PBS at $\mathrm{pH} 7.4$ with $1 \mu \mathrm{g} / \mathrm{mL}$ anti-TTX was 50 , $6,0.3 \mathrm{ng} / \mathrm{mL}$ and the maximum response from the $1 \mu \mathrm{g} / \mathrm{mL}$ anti-TTX reference in PBS was $3.74 \mathrm{~nm}$ [20]. In the previous work, an inhibition assay with $1 \mu \mathrm{g} / \mathrm{mL}$ anti-TTX provided a detection limit approximately one order of magnitude better than $2 \mu \mathrm{g} / \mathrm{mL}$ anti-TTX. The optimized assay for the complex matrices was run at $\mathrm{pH}$ 4.5. Thus, the higher concentration of antibody was chosen because of the lowered antibody response due to antibody-antigen binding dependence on $\mathrm{pH}$.

3.3. Detection of TTX in Complex Media. Figure 3 shows the averaged normalized SPR sensorgrams corresponding to the detection of various concentrations of TTX in buffer and complex media. For each of the complex media, the data was normalized to the response from $2 \mu \mathrm{g} / \mathrm{mL}$ antiTTX in SAB. While it is important to determine calibration curves for unique complex matrices, it is also important to normalize the data to a reproducible standard. For a unique detection matrix, it may not be possible to have a toxinfree sample, so normalizing data to a buffer standard is necessary. In Figures 3(b), 3(c), and 3(d), the sensorgrams show a substantial reponse at 10 minutes and 25 minutes, which does not correspond to the antibody response. This response is a bulk refractive index shift caused by the change in refractive index of the $10 \%$ sample compared to the running buffer. The bulk refractive index shift has no residual effect on antibody binding on the sensing surface. In Figures $3(\mathrm{~b}), 3(\mathrm{c})$, and $3(\mathrm{~d})$ there is one sensorgram that does not exhibit the bulk refractive index response that corresponds to the $10 \%$ sample matrix, these sensorgrams are the antibody reference in buffer with no complex matrix.

Figure 4 is the calibration curves showing normalized wavelength shift versus concentration of TTX in buffer and complex media. The $\mathrm{IC}_{80}, \mathrm{IC}_{50}$, and $\mathrm{IC}_{20}$ should correspond to normalized values of $0.2,0.5$, and 0.8 , respectively. From the data shown in Figure 4, the $\mathrm{IC}_{80}, \mathrm{IC}_{50}$, and $\mathrm{IC}_{20}$ 


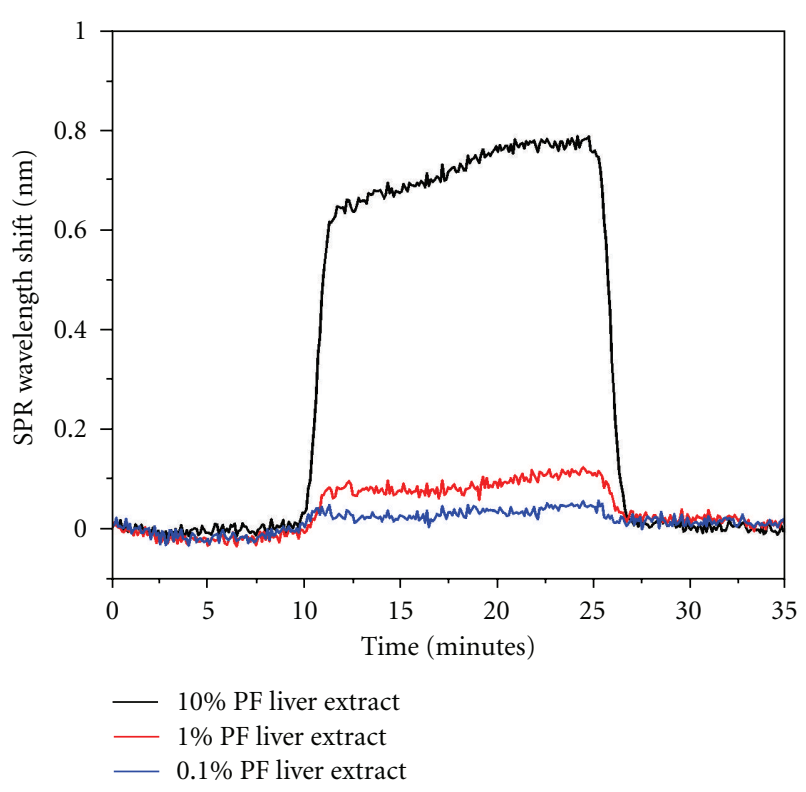

(a)

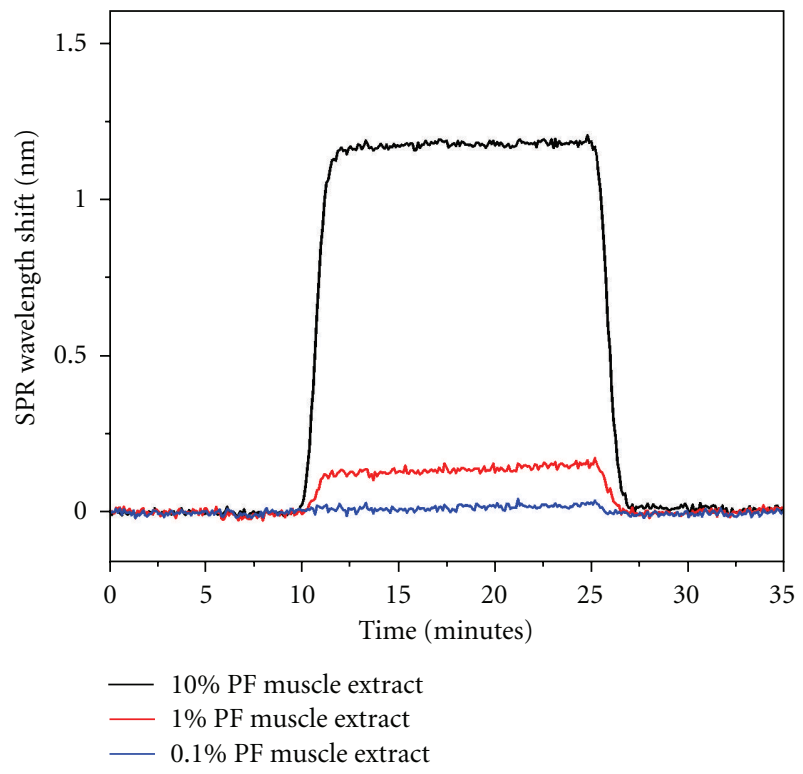

(b)

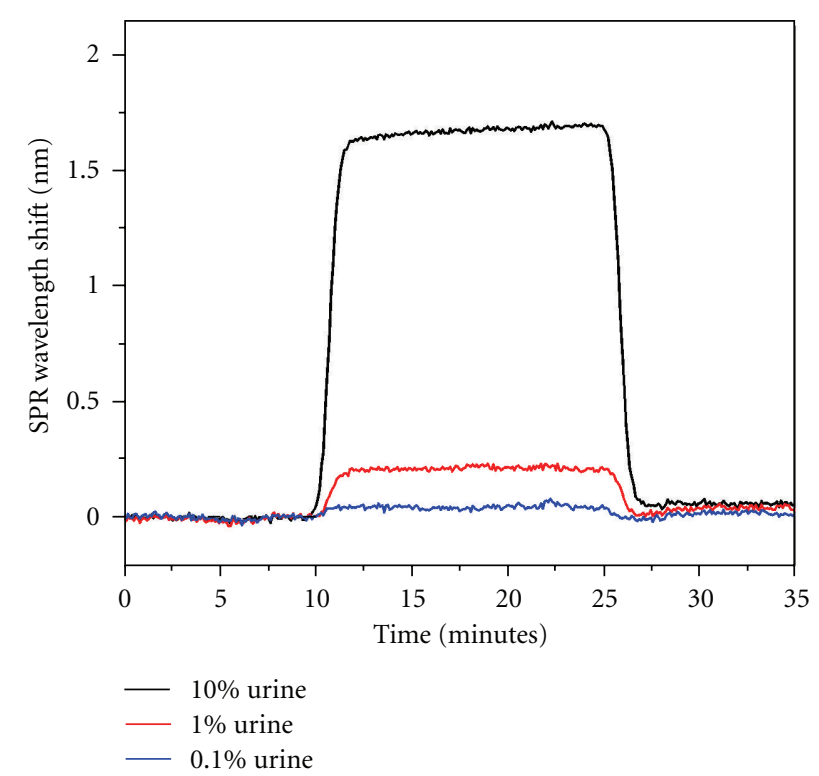

(c)

Figure 2: Control experiments demonstrating that the sensor surfaces are relatively nonfouling to the $10 \%, 1 \%$, and $0.1 \%$ dilutions of complex media: (a) pufferfish liver extract, (b) pufferfish muscle extract, and (c) urine. The complex media were diluted in $100 \mathrm{mM}$ sodium acetate buffer at $\mathrm{pH} 4.5$ with $50 \mathrm{mM} \mathrm{NaCl}$ and $200 \mu \mathrm{g} / \mathrm{mL}$ BSA (SAB). A $1 \mathrm{~nm}$ SPR wavelength shift at $750 \mathrm{~nm}$ to $751 \mathrm{~nm}$ represents a protein surface coverage of $\sim 161 \mathrm{pg} / \mathrm{mm}^{2}$.

for $10 \%$ pufferfish liver extract samples incubated with $2 \mu \mathrm{g} / \mathrm{mL}$ anti-TTX were $95 \mathrm{ng} / \mathrm{mL}, 22 \mathrm{ng} / \mathrm{mL}$, and $1 \mathrm{ng} / \mathrm{mL}$, respectively. So the detection limit corresponds to the $\mathrm{IC}_{20}$ of $1 \mathrm{ng} / \mathrm{mL}$. The $\mathrm{IC}_{80}, \mathrm{IC}_{50}$, and $\mathrm{IC}_{20}$ for $10 \%$ pufferfish muscle extract samples incubated with $2 \mu \mathrm{g} / \mathrm{mL}$ anti-TTX were $200 \mathrm{ng} / \mathrm{mL}, 32 \mathrm{ng} / \mathrm{mL}$, and $6 \mathrm{ng} / \mathrm{mL}$, respectively. So the detection limit corresponds to the $\mathrm{IC}_{20}$ of $6 \mathrm{ng} / \mathrm{mL}$. The $\mathrm{IC}_{80}, \mathrm{IC}_{50}$ and $\mathrm{IC}_{20}$ for $10 \%$ urine samples incubated with $2 \mu \mathrm{g} / \mathrm{mL}$ anti-TTX were $640 \mathrm{ng} / \mathrm{mL}, 53 \mathrm{ng} / \mathrm{mL}$, and
$17 \mathrm{ng} / \mathrm{mL}$, respectively. Thus, the detection limit corresponds to the $\mathrm{IC}_{20}$ of $17 \mathrm{ng} / \mathrm{mL}$.

In the $10 \%$ urine matrix, a higher antibody response was seen which results in a calibration curve that was shifted above the normalized value of one (maximum reference antibody response), when the detections were referenced to antibody response in buffer. Figure 2(c) shows that there was no significant nonspecific binding from the $10 \%$ urine matrix. Also, $10 \%$ urine in $\mathrm{SAB}$ does not cause the $\mathrm{pH}$ to deviate 


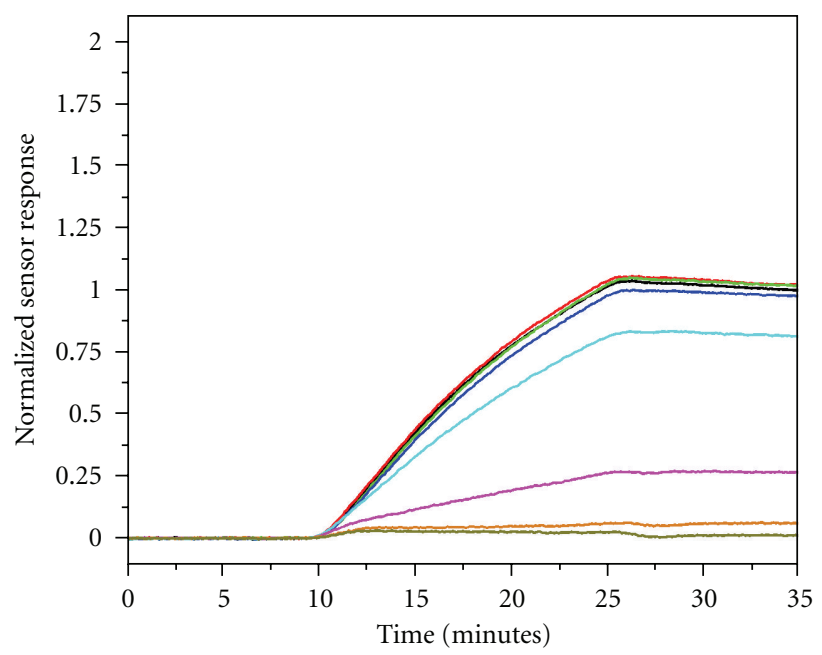

(a)

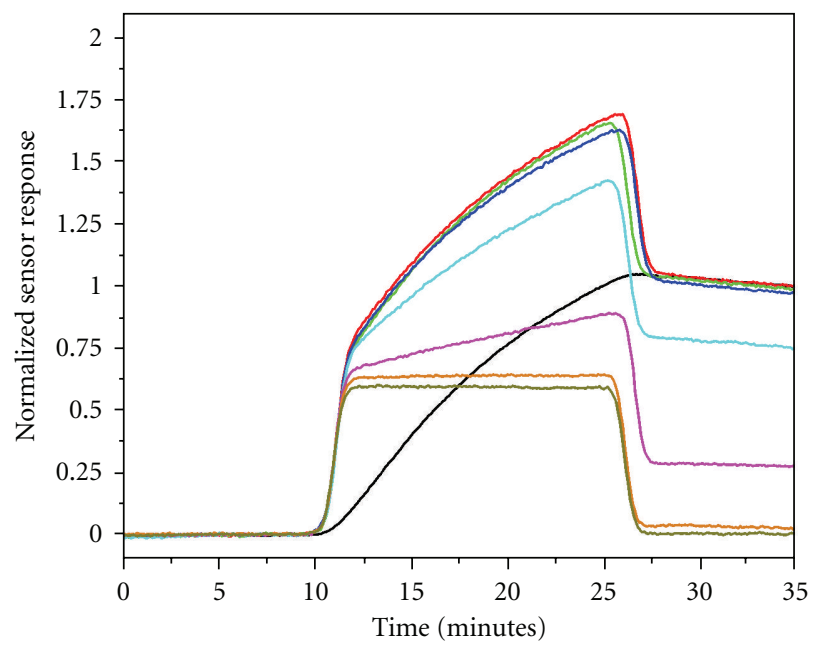

TTX concentration $(\mathrm{ng} / \mathrm{mL})$

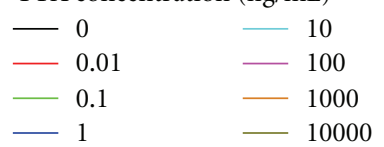

(c)

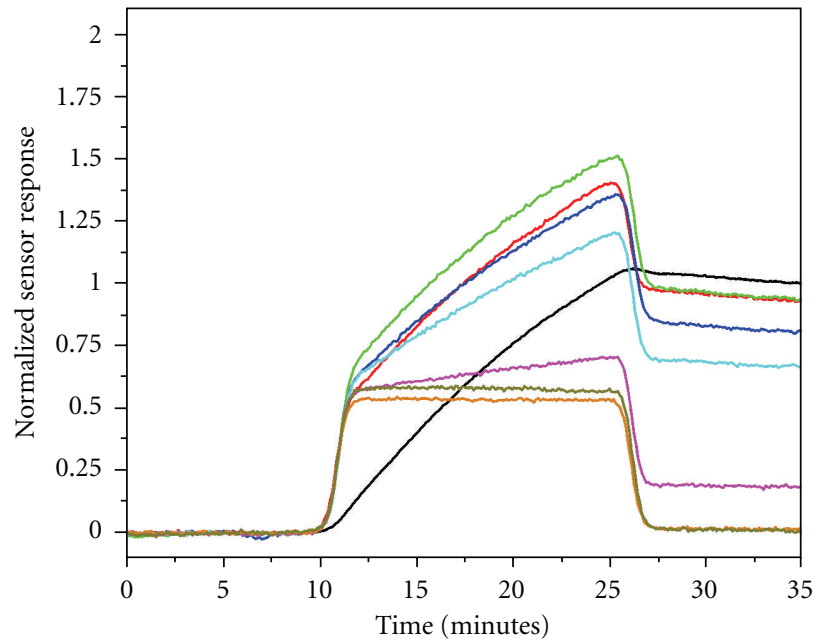

(b)

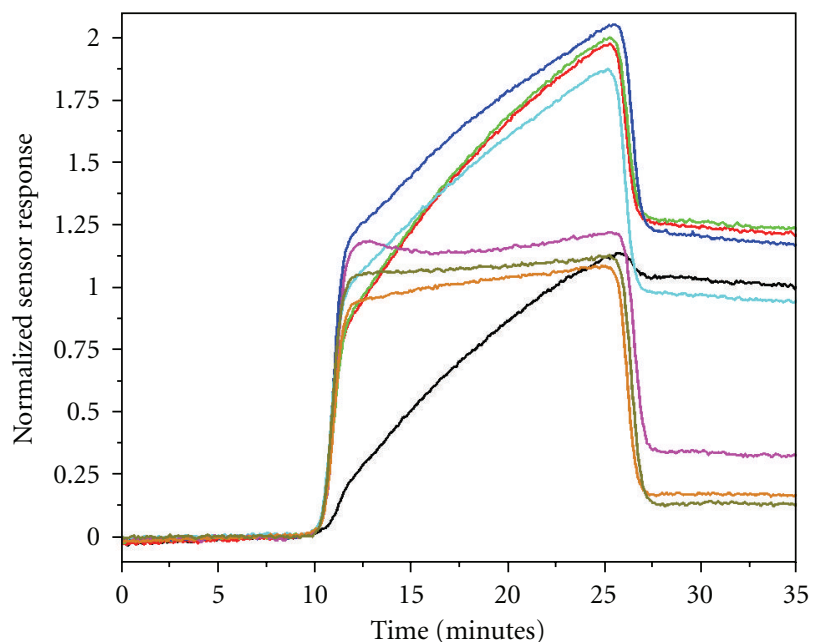

TTX concentration $(\mathrm{ng} / \mathrm{mL})$

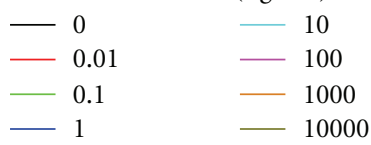

(d)

FIGURE 3: Normalized reference compensated SPR sensorgrams showing sensor responses for $2 \mu \mathrm{g} / \mathrm{mL}$ of anti-TTX antibody incubated with various concentration of TTX in (a) $100 \mathrm{mM}$ sodium acetate buffer at $\mathrm{pH} 4.5$ with $50 \mathrm{mM} \mathrm{NaCl}$ and $200 \mu \mathrm{g} / \mathrm{mL} \mathrm{BSA}$ (SAB), (b) SAB at pH 4.5 with $10 \%$ pufferfish liver extract, (c) SAB at pH 4.5 with $10 \%$ pufferfish muscle extract, and (d) SAB at pH 4.5 with $10 \%$ urine. Samples containing complex media were normalized to an antibody reference in buffer. The data shown is the average from three detection cycles.

from the buffer $\mathrm{pH}$ of 4.5. But as shown in Figure 5(a), the $2 \mu \mathrm{g} / \mathrm{mL}$ anti-TTX response in $10 \%$ urine diluted in $\mathrm{SAB}$ was $1.75 \mathrm{~nm}$, while the response in $10 \%$ water in the same buffer was 1.38 . If the calibration curve is normalized to anti-TTX reference with $10 \%$ urine (Figure 5(b)), the calibration curves normalizes with maximum close to 1 and corresponds well with the detection curve for SAB; however, the calibration curve normalized to reference antibody in $10 \%$ water has an approximately $25 \%$ higher maximum response. From the data shown in Figure 5(b), the $\mathrm{IC}_{80}, \mathrm{IC}_{50}$ and $\mathrm{IC}_{20}$ for samples incubated with $2 \mu \mathrm{g} / \mathrm{mL}$ anti-TTX and normalized to a reference with $10 \%$ urine were $263 \mathrm{ng} / \mathrm{mL}$,
$27 \mathrm{ng} / \mathrm{mL}$, and $3 / \mathrm{mL}$, respectively, compared to $640 \mathrm{ng} / \mathrm{mL}$, $53 \mathrm{ng} / \mathrm{mL}$, and $17 \mathrm{ng} / \mathrm{mL}$, respectively, for the same data normalized to an antibody reference in SAB. However, for the data normalized to antibody reference in $\mathrm{SAB}$, the maximum is $\sim 1.2$ instead of 1 , so the $\mathrm{IC}_{80}, \mathrm{IC}_{50}$, and $\mathrm{IC}_{20}$ should correspond to a value of $0.24,0.6$, and 0.96 instead of 0.2 , 0.5 , and 0.8 . If the values are recalculated using the actual maximum of 1.2 instead of 1 , then the values are the same as for data referenced to antibody in $10 \%$ urine. Since it may be difficult to obtain toxin-free sample, the reference antibody needs to be measured in a standard system (buffer). However, it is necessary to determine quantification from calibration 


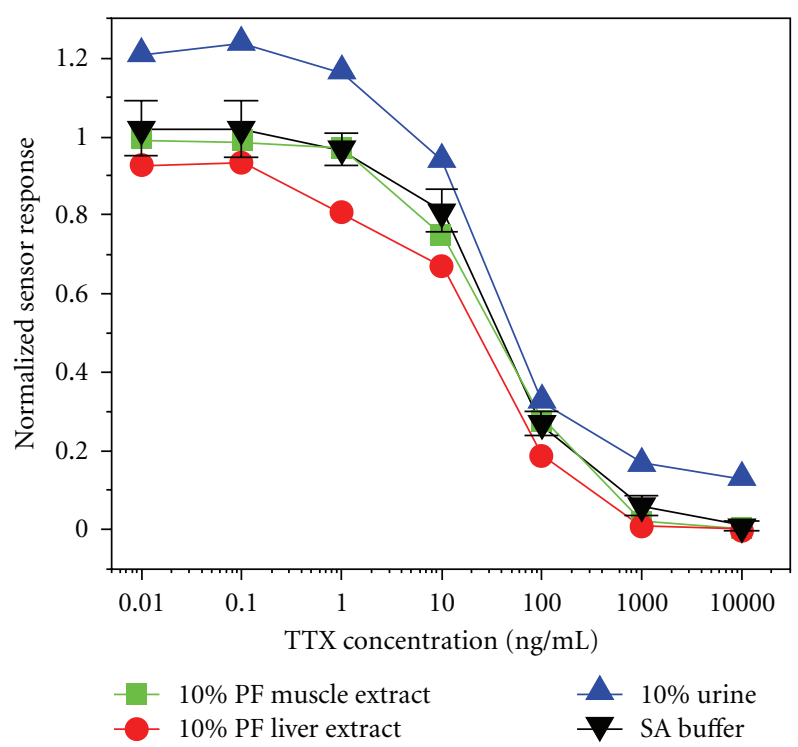

Figure 4: Calibration curves for the detection of TTX in SAB at $\mathrm{pH} 4.5$ and pufferfish liver extract, pufferfish muscle extract, and urine diluted to $10 \%$ in SAB at $\mathrm{pH}$ 4.5. Normalized SPR resonant wavelength shift versus the concentration of TTX incubated with $2 \mu \mathrm{g} / \mathrm{mL}$ anti-TTX for 15 minutes by an inhibition assay. The data from the sensorgram was normalized to the maximum anti-TTX response in $\mathrm{SAB}$.

curves for a specific matrix as opposed to calibration curves for standards detected in buffer. In the case of detection of TTX in urine, the urine matrix affects the antibody response and it is necessary to determine the $\mathrm{IC}_{80}, \mathrm{IC}_{50}$, and $\mathrm{IC}_{20}$ from the actual maximum and minimum values instead of using 1 and 0 as the maximum and minimum value.

3.4. Analysis of Naturally Contaminated Pufferfish Samples. Two samples of naturally contaminated pufferfish extract were prepared and analyzed by LC/ESI/MRM/MS at the US FDA CFSAN and were analyzed by inhibition assay with SPR sensor at the University of Washington laboratory. The samples were prepared from the liver and muscle from the same species of naturally toxic (with TTX) pufferfish. The pufferfish typically accumulates much higher concentration of TTX in the liver than in the muscle [1]; however, the muscle in often consumed as food. The relevant concentrations of TTX in the samples can be much higher than the quantifiable region of the developed TTX assay, so the sample is run at three dilution factors $(10 \%, 1 \%$, and $0.1 \%)$. By testing three dilutions of the sample, the assay can cover three to four orders of magnitude for concentrations of TTX. Figure 6(a) shows the SPR response for 10\%, 1\%, and $0.1 \%$ naturally contaminated pufferfish liver, and the corresponding calibration curve for detection in pufferfish liver. The $0.1 \%$ dilution of pufferfish liver had a detection that fell between the $\mathrm{IC}_{20}$ and $\mathrm{IC}_{80}$ (the quantifiable range). The assay showed that the concentration in the sample was $25 \mathrm{ng} / \mathrm{mL} \pm 8 \mathrm{ng} / \mathrm{mL}$, which corresponds to a concentration in the undiluted sample of $25 \mu \mathrm{g} / \mathrm{mL} \pm 8 \mu \mathrm{g} / \mathrm{mL}$.
This sample had an extraction dilution factor of 2.04, so $2.04 \mathrm{~mL}$ of extract is equivalent to $1 \mathrm{~g}$ of tissue; therefore, the detected value is $5100 \mu \mathrm{g} T \mathrm{TX} / 100 \mathrm{~g}$ of tissue. This value corresponds well with the value for this sample determined by LC/ESI/MRM/MS, which is $4803 \mu \mathrm{g} / 100 \mathrm{~g}$ of tissue. The other dilutions had responses more that $80 \%$ inhibition. Thus, the concentration was too high to reliably quantify. Figure 6(b) shows the SPR response for $10 \%, 1 \%$, and $0.1 \%$ naturally contaminated pufferfish muscle and the corresponding calibration curve for detection of TTX in pufferfish muscle. The $1 \%$ dilution of pufferfish muscle had a detection that fell between the $\mathrm{IC}_{20}$ and $\mathrm{IC}_{80}$. The concentration in the sample was $63 \mathrm{ng} / \mathrm{mL} \pm 14 / \mathrm{mL}$, which corresponds to a concentration in the undiluted sample of $6.3 \mu \mathrm{g} / \mathrm{mL} \pm 1.4 \mu \mathrm{g} / \mathrm{mL}$. This sample had an extraction dilution factor of 2.14 , so $2.14 \mathrm{~mL}$ of extract is from $1 \mathrm{~g}$ of tissue; therefore, detected value is $1285 \mu \mathrm{g} / 100 \mathrm{~g}$ of tissue. This value is approximately double the value for this sample determined by LC/ESI/MRM/MS, which is $582 \mu \mathrm{g} / 100 \mathrm{~g}$ of tissue. The $10 \%$ dilution had a response that is more than $80 \%$ inhibition and the $0.1 \%$ dilution had a response with less than $20 \%$ inhibition, so the concentrations were outside of the quantifiable range.

3.5. Analysis of Poisoning Incident Samples by SPR Sensor and Compared with LC/ESI/MRM/MS. Ten samples of fish muscle tissue extract were analyzed by the SPR sensor assay in the laboratory at the University of Washington and by LC/ESI/MRM/MS at the US FDA CFSAN laboratory. These samples were collected as part of an outbreak of puffer fish poisoning (PFP) that occurred in 2007. The samples were run at $10 \%, 1 \%$, and $0.1 \%$ dilutions in order to assure that one of the dilutions would fall within the quantification range of the calibration curve. The toxin concentration was calculated by normalizing the binding response from the antibody-sample mixture to the response from only the antibody in buffer. Then normalized signal was fit to the quantifiable range of the calibration curve that was collected in pufferfish muscle extract. The results for quantification of TTX by the SPR sensor assay compared to quantification by LC/ESI/MRM/MS are shown in Table 1. By testing three sample dilutions, the detection range for these tests was from 0.1 to $200 \mu \mathrm{g} / \mathrm{mL}$ or assuming an extraction dilution factor of 2, 20 to $40,000 \mu \mathrm{g} / 100 \mathrm{~g}$ of tissue. If the normalized response was greater than the $\mathrm{IC}_{20}$ for a $10 \%$ sample dilution, then the concentration of TTX in the sample was less than $0.1 \mu \mathrm{g} / \mathrm{mL}$ and was characterized in Table 1 as "<LOD." Assuming an extraction dilution factor of 2, then the sample had less than $20 \mu \mathrm{g} / 100 \mathrm{~g}$ of tissue. The detection limit for this matrix and antibody concentration of $20 \mu \mathrm{g}$ TTX/100 g of tissue was comparable to the mouse bioassay which has a detection limit of $0.2 \mu \mathrm{g} / \mathrm{mL}$ or $40 \mu \mathrm{g}$ TTX/100 g [31]. While there is no action level for TTX provided by the US FDA, the action level for saxitoxin (STX), responsible for paralytic shellfish poisoning and similar in pharmacology and potency to TTX [32], is $80 \mu \mathrm{g} / 100 \mathrm{~g}$ of tissue and can be used for comparison. The data from the SPR sensor assay corresponded to quantification determined by LC/ESI/MRM/MS by average within $\sim 29 \%$ for $10 \%$ sample 


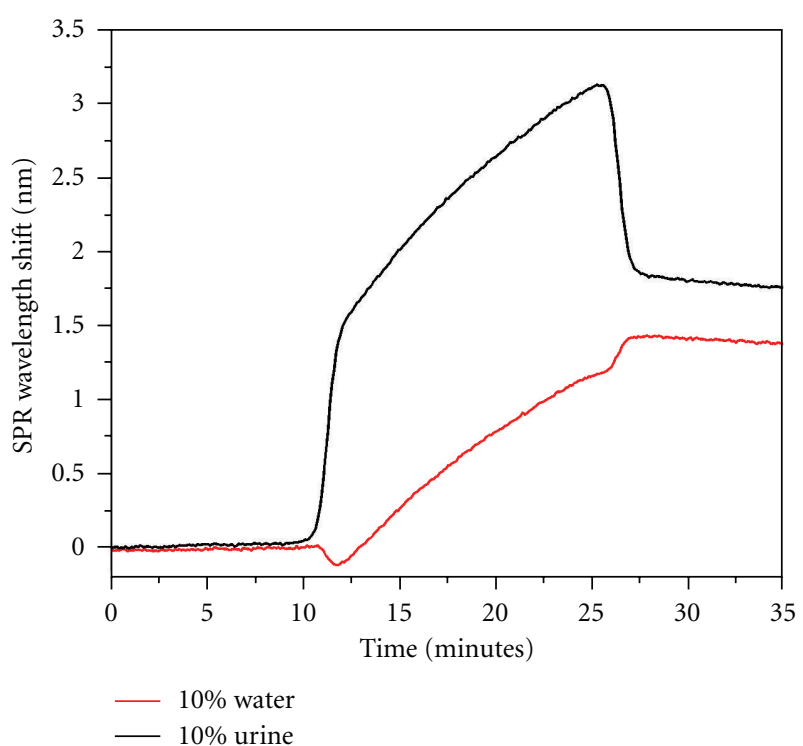

(a)

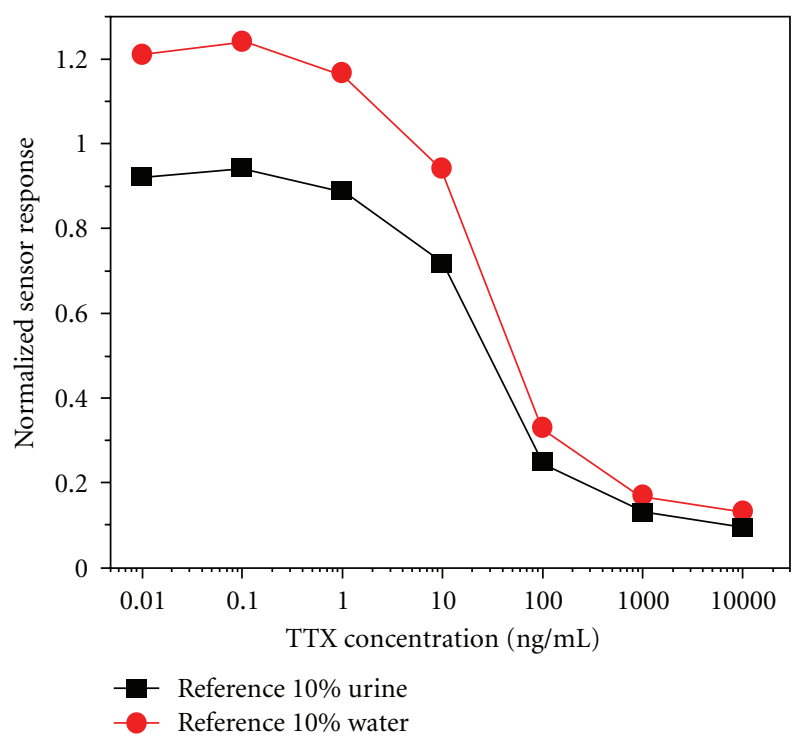

(b)

FIGURE 5: The effect of urine on antibody response. (a) SPR sensorgrams showing sensor responses for $2 \mu \mathrm{g} / \mathrm{mL}$ of anti-TTX in SAB at pH 4.5 with $10 \%$ urine or $10 \%$ water. (b) Calibration curves showing normalized wavelength shift versus concentration of TTX in sample for one set of data normalized to either reference antibody response with $10 \%$ urine or $10 \%$ water. The reference antibody response in urine was $\sim 25 \%$ higher than in buffer without urine. A $1 \mathrm{~nm}$ SPR wavelength shift at $750 \mathrm{~nm}$ to $751 \mathrm{~nm}$ represents a protein surface coverage of $\sim 161 \mathrm{pg} / \mathrm{mm}^{2}$.



(a)

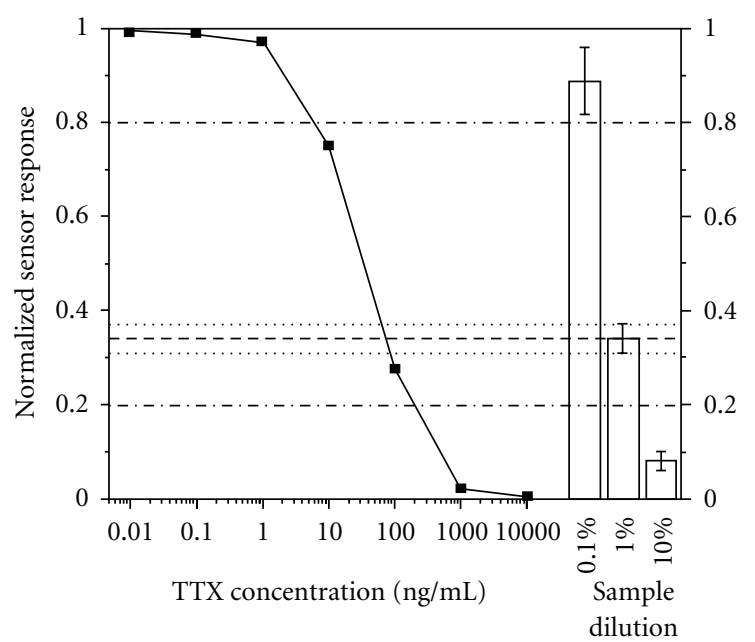

(b)

FIGURE 6: Analysis of (a) naturally contaminated puffer fish liver sample and (b) naturally contaminated puffer fish muscle sample.

dilutions and $\sim 57 \%$ for $1 \%$ sample dilutions. For all but one sample that provided a detectable concentration of TTX, the SPR method predicted a concentration lower than determined by LC/ESI/MRM/MS. For samples that were quantified with $10 \%$ and $1 \%$ sample dilutions, the $10 \%$ sample always predicted a concentration higher than $1 \%$ sample by an average of $\sim 23 \%$. The lower predicted values for the $1 \%$ samples compared to $10 \%$ samples may be caused by a matrix effect, since the $1 \%$ samples were quantified by comparison to the calibration curve produced from $10 \%$ pufferfish liver in SAB. The two samples that had the highest concentration of TTX, "Raw Puffer 3" and "Raw Puffer 4," had values for the $10 \%$ dilution that were below the $\mathrm{IC}_{80}$, but still above the $\mathrm{IC}_{90}$, the predicted values from this data still corresponded well with the values from the $1 \%$ dilution and have good predictive value. 
TABLE 1: Results of TTX in ten fish tissue extract samples measured by an SPR biosensor assay compared with LC/ESI/MRM/MS data.

\begin{tabular}{|c|c|c|c|c|c|}
\hline Source & $\begin{array}{l}\text { Sample } \\
\text { dilution }\end{array}$ & $\begin{array}{c}\text { SPR } \\
(\mu \mathrm{g} / \mathrm{mL} \text { extract }) \\
\end{array}$ & $\begin{array}{c}\text { Extraction } \\
\text { dilution }\end{array}$ & $\begin{array}{c}\text { SPR } \\
(\mu \mathrm{g} / 100 \mathrm{~g} \text { sample })\end{array}$ & $\begin{array}{l}\text { LC/ESI/MRM/MS } \\
(\mu \mathrm{g} / 100 \mathrm{~g} \text { sample })\end{array}$ \\
\hline \multirow{2}{*}{ Cooked Fish Flesh 1} & $10 \%$ & $1.6 \pm 0.4$ & \multirow[b]{2}{*}{2.01} & $322 \pm 80$ & \multirow[b]{2}{*}{374} \\
\hline & $1 \%$ & $1.2 \pm 0.4$ & & $241 \pm 80$ & \\
\hline \multirow{2}{*}{ Cooked Fish Flesh 2} & $10 \%$ & $2.5 \pm 1.2$ & \multirow[b]{2}{*}{1.95} & $488 \pm 234$ & \multirow[b]{2}{*}{655} \\
\hline & $1 \%$ & $1.8 \pm 0.3$ & & $351 \pm 59$ & \\
\hline \multirow{2}{*}{ Soup Broth } & $10 \%$ & $1.2 \pm 0.4$ & \multirow[b]{2}{*}{1.97} & $236 \pm 79$ & \multirow[b]{2}{*}{361} \\
\hline & $1 \%$ & $0.8 \pm 0.2$ & & $158 \pm 39$ & \\
\hline Raw Puffer 1 & $10 \%$ & $<\mathrm{LOD}$ & 1.89 & ND & 10 \\
\hline \multirow{2}{*}{ Raw Puffer 2} & $10 \%$ & $2.4 \pm 0.6$ & \multirow[b]{2}{*}{1.89} & $454 \pm 113$ & \multirow[b]{2}{*}{214} \\
\hline & $1 \%$ & $1.8 \pm 0.4$ & & $340 \pm 76$ & \\
\hline \multirow{2}{*}{ Raw Puffer 3} & $10 \% *$ & $4.5 \pm 0.9$ & \multirow[b]{2}{*}{1.86} & $837 \pm 167$ & \multirow[b]{2}{*}{876} \\
\hline & $1 \%$ & $4.4 \pm 1.4$ & & $818 \pm 260$ & \\
\hline \multirow{2}{*}{ Raw Puffer 4} & $10 \% *$ & $4.2 \pm 0.3$ & \multirow[b]{2}{*}{2.01} & $844 \pm 60$ & \multirow[b]{2}{*}{961} \\
\hline & $1 \%$ & $3.8 \pm 0.5$ & & $764 \pm 101$ & \\
\hline Raw Puffer 5 & $10 \%$ & $<$ LOD & 2.02 & $<$ LOD & 10 \\
\hline Monkfish 1 & $10 \%$ & $<\mathrm{LOD}$ & 1.78 & $<\mathrm{LOD}$ & $\mathrm{ND}$ \\
\hline Monkfish 2 & $10 \%$ & $<\mathrm{LOD}$ & 1.98 & $<\mathrm{LOD}$ & ND \\
\hline
\end{tabular}

${ }^{*}$ Below $\mathrm{IC}_{80}$, above $\mathrm{IC}_{90},<\mathrm{LOD}$ : below limit of detection, ND: not detected.

\section{Conclusions}

The optimized assay was successfully used to detect TTX in naturally contaminated samples of pufferfish liver and pufferfish muscle. The data corresponded well with the concentration of TTX in the samples determined by LC/ESI/ MRM/MS, demonstrating the ability of the TTX inhibition assay by SPR sensor to detect and quantify TTX in real samples.

The detection of TTX in the complex matrices of human urine, pufferfish liver extract, and pufferfish muscle extract required optimization of the running buffer. The optimized buffer conditions for these complex media were determined to be $100 \mathrm{mM}$ sodium acetate buffer at pH 4.5 with $50 \mathrm{mM}$ $\mathrm{NaCl}$ and $200 \mu \mathrm{g} / \mathrm{mL}$ BSA. Changing the $\mathrm{pH}$ of the assay from 7.4 to 4.5 caused the overall antibody response to be lowered from $\sim 7.5 \mathrm{~nm}$ to $\sim 1.6 \mathrm{~nm}$ of SPR wavelength shift for $2 \mu \mathrm{g} / \mathrm{mL}$ anti-TTX. The calibration curves for pufferfish liver extract and pufferfish muscle extract corresponded well with the calibration curves for detection in buffer. However, the calibration curve for urine normalized to antibody response in buffer had a $\sim 25 \%$ higher maximum response than the calibration curve in buffer. If the calibration curve for detection in urine was normalized to the antibody response in $10 \%$ urine then the calibration curve corresponds well with that for detection in buffer. Control experiments show that there in no significant nonspecific response from any of the complex media using the optimized assay buffer, and the $\mathrm{pH}$ of the $10 \%$ urine sample is the same as the buffer. Thus, the higher antibody response was caused by the urine matrix, resulting in the shifted calibration curve for data normalized to a reference antibody in buffer. The optimized inhibition immunoassay for detection of TTX in complex matrices using an SPR sensor correlated well with analysis by LC/ESI/MRM/MS. The developed method provides a robust and regenerable assay for the sensitive and quantitative detection of TTX in complex matrices.

\section{Acknowledgments}

The authors are grateful to Betsy Yakes for her comments and revision of this paper prior to submission. This project was supported by the National Research Initiative of the USDA Cooperative State Research, Education and Extension Service, Grant no. 2005-35201-16321 and the United States Food and Drug Administration, Grant no. HHSF223200610011. Allen D. Taylor was partially supported by the Intel Foundation Ph.D. Fellowship Award and the Kaiser Aluminum Fellowship Award at the University of Washington.

\section{References}

[1] T. Noguchi, O. Arakawa, and T. Takatani, "TTX accumulation in pufferfish," Comparative Biochemistry and Physiology-Part D: Genomics and Proteomics, vol. 1, no. 1, pp. 145-152, 2006.

[2] W. A. Catterall, "Structure and function of voltage-sensitive ion channels," Science, vol. 242, no. 4875, pp. 50-61, 1988.

[3] G. K. Isbister, "Marine envenomation and poisoning," in Medical Toxicology, R. C. Dart, Ed., chapter 252, pp. 16211644, Lippincott Williams \& Wilkins, Philadelphia, Pa, USA, 3rd edition, 2004.

[4] A. Alcaraz, R. E. Whipple, H. R. Gregg, B. D. Andresen, and P. M. Grant, "Analysis of tetrodotoxin," Forensic Science International, vol. 99, no. 1, pp. 35-45, 1999.

[5] T. J. G. Raybould, G. S. Bignami, L. K. Inouye et al., "A monoclonal antibody-based immunoassay for detecting 
tetrodotoxin in biological samples," Journal of Clinical Laboratory Analysis, vol. 6, no. 2, pp. 65-72, 1992.

[6] C. K. How, C. H. Chern, Y. C. Huang, L. M. Wang, and C. H. Lee, "Tetrodotoxin poisoning," American Journal of Emergency Medicine, vol. 21, no. 1, pp. 51-54, 2003.

[7] E. J. Nuñez-Vázquez, M. Yotsu-Yamashita, A. P. Sierra-Beltrán, T. Yasumoto, and J. L. Ochoa, "Toxicities and distribution of tetrodotoxin in the tissues of puffer fish found in the coast of the Baja California Peninsula, Mexico," Toxicon, vol. 38, no. 5, pp. 729-734, 2000.

[8] K. Kawatsu, T. Shibata, and Y. Hamano, "Application of immunoaffinity chromatography for detection of tetrodotoxin from urine samples of poisoned patients," Toxicon, vol. 37, no. 2, pp. 325-333, 1999.

[9] Y. H. Tsai, D. F. Hwang, C. A. Cheng, C. C. Hwang, and J. F. Deng, "Determination of tetrodotoxin in human urine and blood using C18 cartridge column, ultrafiltration and LCMS," Journal of Chromatography B: Analytical Technologies in the Biomedical and Life Sciences, vol. 832, no. 1, pp. 75-80, 2006.

[10] T. Yasumoto, "The manual for the methods of food sanitation tests," in Bureau of Environmental Health and Welfare, for Chemistry, p. 296, Japan Food Hygienic Association, Tokyo, Japan, 1991

[11] S. Gallacher, F. Mackintosh, A. M. Shanks, S. O’Neill, I. Riddoch, and F. G. Howard, "Monitoring for paralytic shellfish poisons in Scotland and progress in research to replace the use of the mouse bioassay," Journal of Shellfish Research, vol. 17, no. 5, pp. 1647-1651, 1998.

[12] M. LeDoux, S. Hall, M. Bohec et al., "Proficiency testing of eight French laboratories in using the AOAC mouse bioassay for paralytic shellfish poisoning: interlaboratory collaborative study," Journal of AOAC International, vol. 83, no. 2, pp. 305$310,2000$.

[13] G. J. Doucette, C. L. Powell, E. U. Do, C. Y. Byon, F. Cleves, and S. G. McClain, "Evaluation of 11-[3H]-tetrodotoxin use in a heterologous receptor binding assay for PSP toxins," Toxicon, vol. 38, no. 11, pp. 1465-1474, 2000.

[14] K. Hamasaki, K. Kogure, and K. Ohwada, "An improved method of tissue culture bioassay for tetrodotoxin," Fisheries Science, vol. 62, no. 5, pp. 825-829, 1996.

[15] B. S. Cheun, M. Loughran, T. Hayashi, Y. Nagashima, and E. Watanabe, "Use of a channel biosensor for the assay of paralytic shellfish toxins," Toxicon, vol. 36 , no. 10, pp. 13711381, 1998.

[16] M. A. O’Leary, J. J. Schneider, and G. K. Isbister, “Use of high performance liquid chromatography to measure tetrodotoxin in serum and urine of poisoned patients," Toxicon, vol. 44, no. 5, pp. 549-553, 2004.

[17] Y. Shoji, M. Yotsu-Yamashita, T. Miyazawa, and T. Yasumoto, "Electrospray ionization mass spectrometry of tetrodotoxin and its analogs: liquid chromatography/mass spectrometry, tandem mass spectrometry, and liquid chromatography/ tandem mass spectrometry," Analytical Biochemistry, vol. 290, no. 1, pp. 10-17, 2001.

[18] K. Kawatsu, Y. Hamano, T. Yoda, Y. Terano, and T. Shibata, "Rapid and highly sensitive enzyme immunoassay for quantitative determination of tetrodotoxin," Japanese Journal of Medical Science and Biology, vol. 50, no. 3, pp. 133-150, 1997.

[19] D. Neagu, L. Micheli, and G. Palleschi, "Study of a toxinalkaline phosphatase conjugate for the development of an immunosensor for tetrodotoxin determination," Analytical and Bioanalytical Chemistry, vol. 385, no. 6, pp. 1068-1074, 2006.
[20] A. D. Taylor, J. Ladd, S. Etheridge, J. Deeds, S. Hall, and S. Jiang, "Quantitative detection of tetrodotoxin (TTX) by a surface plasmon resonance (SPR) sensor," Sensors and Actuators B: Chemical, vol. 130, no. 1, pp. 120-128, 2008.

[21] J. Homola, "Present and future of surface plasmon resonance biosensors," Analytical and Bioanalytical Chemistry, vol. 377, no. 3, pp. 528-539, 2003.

[22] P. Pattnaik and A. Srivastav, "Surface plasmon resonanceapplications in food science research: a review," Journal of Food Science and Technology, vol. 43, no. 4, pp. 329-336, 2006.

[23] C.-Y. Chen and H.-N. Chou, "Detection of tetrodotoxin by high performance liquid chromotography in lined-moon shell and puffer fish," Acta Zoologica Taiwanica, vol. 9, no. 1, pp. 4148, 1998.

[24] A. Negri, D. Stirling, M. Quilliam et al., "Three novel hydroxybenzoate saxitoxin analogues isolated from the dinoflagellate Gymnodinium catenatum," Chemical Research in Toxicology, vol. 16, no. 8, pp. 1029-1033, 2003.

[25] J. Ladd, C. Boozer, Q. Yu, S. Chen, J. Homola, and S. Jiang, "DNA-directed protein immobilization on mixed selfassembled monolayers via a streptavidin bridge," Langmuir, vol. 20, no. 19, pp. 8090-8095, 2004.

[26] X. Qian, S. J. Metallo, I. S. Choi, H. Wu, M. N. Liang, and G. M. Whitesides, "Arrays of self-assembled monolayers for studying inhibition of bacterial adhesion," Analytical Chemistry, vol. 74, no. 8, pp. 1805-1810, 2002.

[27] T. M. Blättler, S. Pasche, M. Textor, and H. J. Griesser, "High salt stability and protein resistance of poly(L-lysine)g- poly(ethylene glycol) copolymers covalently immobilized via aldehyde plasma polymer interlayers on inorganic and polymeric substrates," Langmuir, vol. 22, no. 13, pp. 57605769, 2006.

[28] S. Pasche, M. Textor, L. Meagher, N. D. Spencer, and H. J. Griesser, "Relationship between interfacial forces measured by colloid-probe atomic force microscopy and protein resistance of poly(ethylene glycol)-grafted poly(L-lysine) adlayers on niobia surfaces," Langmuir, vol. 21, no. 14, pp. 6508-6520, 2005.

[29] R. E. Holmlin, X. Chen, R. G. Chapman, S. Takayama, and G. M. Whitesides, "Zwitterionic SAMs that resist nonspecific adsorption of protein from aqueous buffer," Langmuir, vol. 17, no. 9, pp. 2841-2850, 2001.

[30] Z. Zhang, S. Chen, and S. Jiang, "Dual-functional biomimetic materials: nonfouling poly(carboxybetaine) with active functional groups for protein immobilization," Biomacromolecules, vol. 7, no. 12, pp. 3311-3315, 2006.

[31] T. Kawabata, "Assay method for tetrodotoxin," in Food Hygiene Examination Manual, T. Kawabata, Ed., vol. 2, pp. 232-239, Japanese Food Hygiene Association, Tokyo, Japan, 1978.

[32] H. Denac, M. Mevissen, and G. Scholtysik, "Structure, function and pharmacology of voltage-gated sodium channels," Naunyn-Schmiedeberg's Archives of Pharmacology, vol. 362, no. 6, pp. 453-479, 2000. 

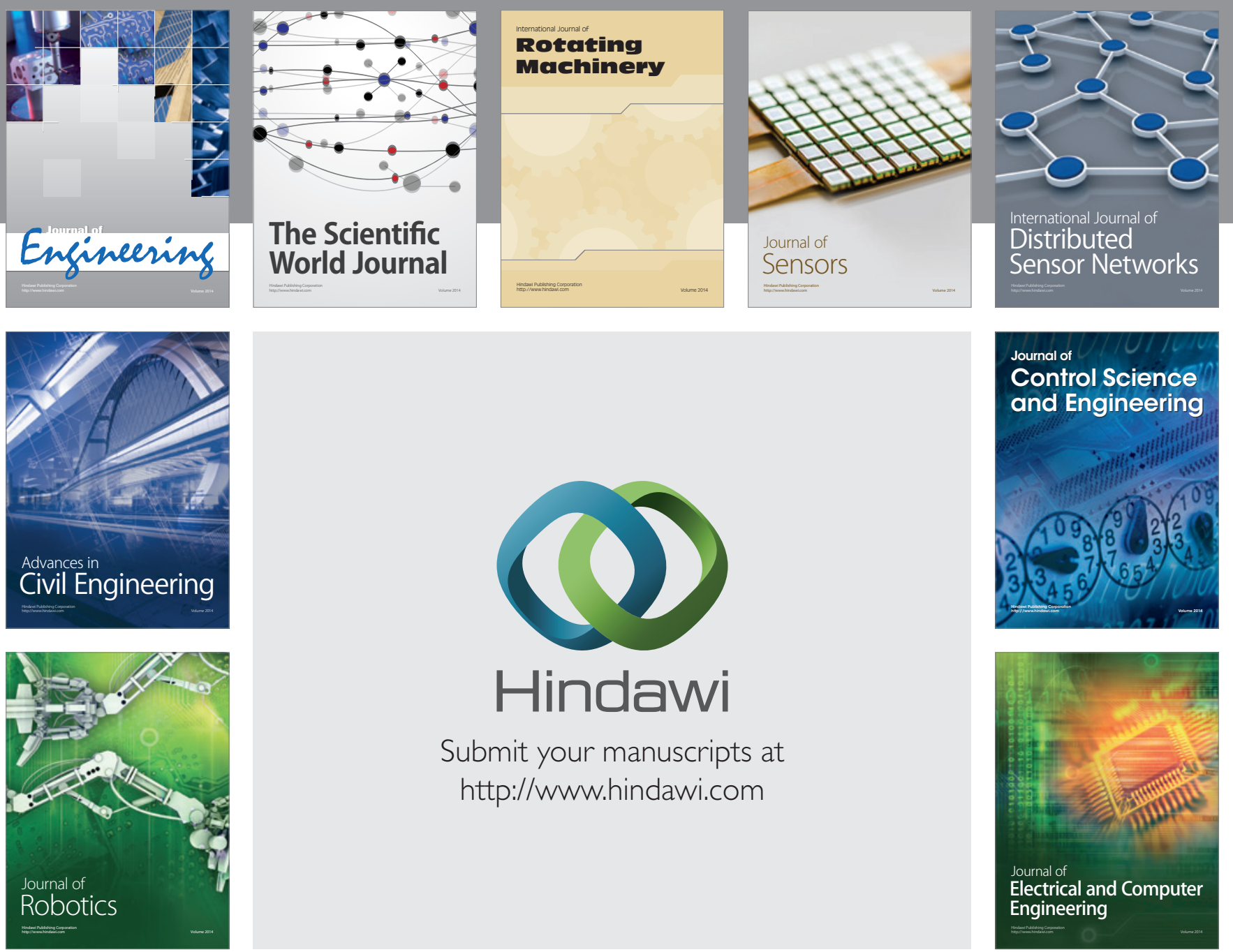

Submit your manuscripts at

http://www.hindawi.com
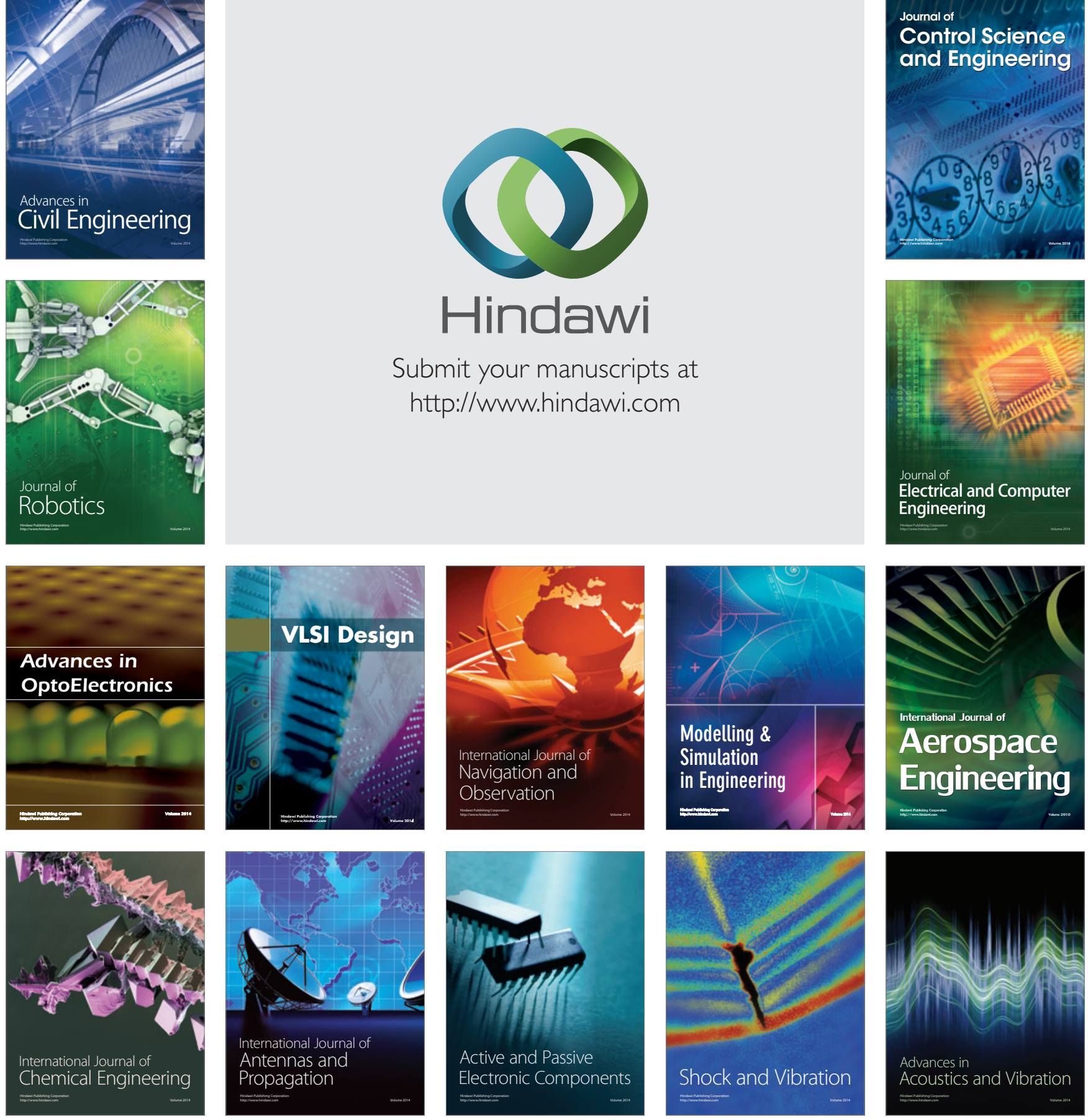